\title{
Potential Employee Fraud Scape in Islamic Banks: The Fraud Triangle Perspective
}

\author{
Wan Nor Iffah Wan Mohd Fathi (Corresponding author) \\ Faculty of Accountancy \\ Universiti Teknologi MARA, Malaysia \\ No Tel:- 603-32587327Email: iffahhafiza266@gmail.com \\ Erlane K Ghani \\ Accounting Research Institute \\ Universiti Teknologi MARA, Malaysia \\ No Tel:+60 03-3258 7404 Email: erlanekg@salam.uitm.edu.my \\ Jamaliah Said \\ Accounting Research Institute \\ Universiti Teknologi MARA, Malaysia \\ No Tel:+60+603 55444891 Email: jamaliah533@salam.uitm.edu.my \\ Evita Puspitasari \\ Faculty of Economics and Business \\ Universitas Padjadjaran, Indonesia \\ No Tel:+ 0222509055 Email: evitapuspitagumilar@gmail.com
}

\begin{abstract}
Fraud committed by employees has become a serious issue as it impacts the reputation of an organisation as well as ruining employees' morality. Many of the fraud cases previously reported were from the conventional banks and little attention has been given to fraud cases in Islamic banks. This study examines whether Islamic bank employees' profile may influence them to commit fraud. Specifically, this study aims to examine whether gender, age, position and religiosity would influence them to commit asset misappropriation. Utilising the Fraud Triangle model, this study conducts questionnaire survey to 109 employees in Islamic banks in Malaysia. The results show significant relationship on gender, age, position and religiosity in influencing the bank employees to commit asset misappropriation in the Islamic banks. The findings in this study indicates that higher authority of the Islamic banks need to outline various plans or programs in preventing fraud in their organisations. The findings in this
\end{abstract}

study contributes to the literature and to the practitioners on the potential factors that may influence asset misappropriation.

Keywords: Employees; Bank; Fraud perpetration; Fraud triangle Theory; Religiosity; Malaysia

Introduction

There is an increase in the public concern regarding the matter of unethical conducts as the public generally perceived that businesses do not put much supervision in their operations (Alam, 1995). This concern is legitimate in view of the high profile corporate scandals around the globe such as Enron in the US and Transmile in Malaysia (Peterson \& Buckhoff, 2004; Bierstaker, Brody \& Pacini 2006). Further, the level of fraud varies from one country to another and from one organisation to another (Rezaee, Crumbley \& Elmore 2004). Upon investigation, these studies found that the employees that mostly involved in fraud are the top executives. Arguably, the fundamentals of these scandals are 
not a matter of lacking in intelligence but instead, a lack of ethics (Giacalone \& Jurkiewicz, 2004). CIFAS (2013) indicated that fraud by employees has been a serious issue that recently grows due to investigations, confirmed cases, referrals and also unconfirmed cases. This trend badly impacts businesses reputation as well as ruining employees' morality due to great cash losses.

A report by KPMG Fraud Survey (2013) in Malaysia has indicated $52 \%$ of the respondents agreed that fraud is a major problem in their organisation, while $83 \%$ stated fraud as a major problem for Malaysian businesses as a whole. Out of the $52 \%$ that have responded that fraud is a major problem for their organisation, $90 \%$ of the respondents felt that fraud is an inevitable cost in a business. The report also reported $89 \%$ of the respondents felt that the quantum of fraud has increased over the years with $94 \%$ respondents agreed that the modus operandi of committing fraud has become more sophisticated and $85 \%$ respondents opined that the increase in fraud occurrences aligned with the number and size of industries. In addition, Superintendent Harjinder Kaur Gurdial Singh in the Bernama (2013) has indicated that the number of fraud occurrences among bank employees has become alarming since the number of losses has increased to RM473.82 million within a span of five years. He reported that $60 \%$ fraud are committed by employees, $30 \%$ fraud are committed by top management and the remaining $10 \%$ are committed by the accountholders. However, many of these fraud cases from found in conventional banks, casting a doubt on whether similar scenario may also likely to happen in Islamic banks.

There is a long recognition on the role of religiosity in guiding human attitude and the current trend is towards re-emphasis of organised religiosity (Arnould \& Zikhan, 2004). The element of religiosity may be able to deter the potential fraud perpetrators to commit fraud, thus establishing the need of this element to be included to the Fraud Triangle theory. This study aims to examine the employees' profile in influencing them to commit fraud. Specifically, this study examines whether gender, age, position and religiosity influence them to commit asset misappropriation. This study utilises the Fraud Triangle model namely pressure, opportunity and rationalisation. The remainder of this paper is structured as follows. The next presents the literature review. This is followed by the literature review and the research design. Then, the research hypotheses development and the results of this study are provided. The last section, summarises and concludes this chapter.

\section{Literature Review}

Any organisation is prone to fraud, an act of deception performed to gain something of value from others in an illegal way, either through being forced or by trickery (Albrecht, Albrecht, \& Albrecht 2006). Levi (2010) defined fraud as "the obtaining of goods and/or money by deception. It is an intentional act made by one or more individuals among management, employees or third parties who produce errors in financial reporting. In other words, it is a misrepresentation or negligence of a truth for the purpose of manipulating the financial information to harm the organisation (Adeneji, 2004; Stewart, 2007). In reality, fraud does not only happen in conventional banks, but also in Islamic banks. Today's Islamic banking is growing very fast around the world. They are widely accepted by both Muslims and nonMuslims. Islamic banks are those with banking systems that are based on shariah law with their main principle is to conduct business by sharing profit and loss and to strictly prohibit interest earning and rewarding. This verse provides the general meaning of fraud where Allah s.w.t has prohibited Muslim to consume others' wealth unjustly. Therefore, any activities that lead to such action are considered as fraud. Islam prohibits every type of fraud and deception, whether the fraud in activities of buying and selling or in any other matter between people. 
Fraud committed by employees against the organisation can be done in several ways. As reported in the ACFE Report to the Nations on Occupational Fraud and Abuses (2014), occupational fraud can be classified into three different classifications namely, corruption, financial statement fraud and asset misappropriation (Steward, 2007). Asset misappropriation is an employee fraud that is less discussed in previous studies due to the studies on fraud have mostly focused on corruption and financial statement fraud. In addition, most studies on fraud concerned on asset misappropriation in a conventionally-based organisation, but in the real world, Islamicbased institutions are also experiencing the same (RICK, 2011; Rezaee \& Davani, 2013). Campos and Pradhan (2007) proposed that the incidence of asset misappropriation occurs when the employees such as the government servants used the official vehicles, computers and facilities for personal interest. The episode runs from small misuse of stationeries to misuse of official vehicles (Orchard, Decker and Kiziran, 2007). Chapple, Ferguson and Kang (2007) also indicated that asset misappropriation committed by employees are often in relatively small and immaterial amounts, which therefore, they are difficult to detect.

The Fraud Triangle model has been widely accepted as the general cognitive idea to describe the situation (Murphy \& Dacin, 2011). This model depicts three factors that influence employees' fraud namely, perceived pressure, perceived opportunity and perceived rationalisation. Perceived pressure can badly lead a person to act improperly, and according to Holtfreter, Reisig, Mears \& Wolfe (2010), a person who works under pressure regardless of the monetary or non-monetary aim would probably commit fraud. This may persuade them to act in an unethical manner just to be safe in certain situations. The second element of Fraud Triangle model is perceived opportunity. The opportunity refers to the situation, environment or the system in an organisation that may create some spaces or abilities to its employees to commit fraud (Siregar and Tenoyo, 2015). Another element in the model is perceived rationalisation, in which a person's mind on something may lead him or her to do in such way. In a situation where pressure and opportunity exist, a fraudster would usually justify his or her action by rationalising it as a norm to make it seems legal and acceptable (ACFE 2014).

Studies have identified several factors that influence the employees to commit fraud. A group of studies found that gender can influence the employees to commit fraud (Beltramini, Peterson \& Kozmetsky, 1984; Miesing \& Preble, 1985; Rest, 1986; Ruegger \& King, 1992) with mixed findings. Beltramini et al. (1984) found that female college students have more concern on ethical issues as compared to the male. Their result was supported by Miesing \& Preble (1985). However, Rest (1986) found no significant difference between males and females in doing fraudulent actions. There are also studies that found that age influence employees to commit fraud. CIFAS (2013) conducted a study of fraudsters' profile. They found that the young and educated employees are the ones likely to commit fraud. They attributed the reasons for the young employees to commit fraud is due to the low starting salary with high aspiration for luxury lifestyle. On the other hand, the older generation employees were said to commit less fraud because they have already achieved a certain level of career and hence, they try to sustain and secure their job. However, the type of fraud committed by the internal fraudsters normally depends on their ability to access information and what techniques they use in their fraudulent actions (CIFAS, 2013).

The position that an employee holds could also lead to employees committing fraud. Ewa and Udoayang (2012) identified several situations such as the absent or ineffective controls, lack of supervision or inadequate segregation of duties may create chances or opportunities to commit fraud (Kenyon and Tilton, 2006). In addition, 
most employees and managers who commit fraud tend to have a long tenure with organisation. In other words, since they are already had too many knowledge about the organisation, then it will be easier for them to manipulate the situation. In the context of religiosity, from the Islamic viewpoint, religiosity means the awareness or consciousness of God as well as the desire to ensure balance between worldly needs and adherence to God's commands (Fariza and Yusof, 2015). Therefore, religion is a tool in controlling human behaviour besides building the quality towards faithfulness and acquiescence. For Muslims, Islam is a religion of pillar that shapes the conduct and behaviour of its believers (Jamal, 2003). Many studies have been conducted that show how religiosity impacts on humans' daily behaviours and how it leads human into the way they should be (fitrah). However, Muslims are also human beings with similar risk exposure towards fraud perpetration due to certain causes or motives (Rezaee \& Davani, 2013). There has yet to be a study that examines the factors that influence the employees' perception of the Fraud Triangle model.

\section{Hypotheses Development}

Previous studies have provided mixed findings on whether gender affects fraud. According to Beltramini et al. (1984), female college students have more concern on ethical issues as compared to the male students. The result was supported by Miesing and Preble (1985) where they found females tend to be more ethical than males. However, a study conducted by Rest (1986) has found no significant difference between males and females in doing fraudulent actions. Therefore, this leads to the first research hypothesis in this study.

$\boldsymbol{H}_{1}:$ There is no significant difference between employees' gender on the Fraud Triangle model.

There are studies that have examined the link between age and fraud occurrences. Mackevicius and Griunas (2013) found a direct relationship between age of employees and the volume of the fraud committed. They reported that, the older employees are usually more familiar with the working environment and have a better understanding on the internal control loopholes. As a consequence, it provides more opportunities for them to act fraudulently. They also reported that the number of fraud perpetrated by younger employees with age 25 years old and below are lesser because of less responsibility held by them in the organisation and hence, it was not exposing them to opportunities to commit fraud. As the junior, they are closely monitored by their employers. At the young age, they are encouraging to maintain good reputation in the current organisation they are working with in order to seek for career advancement since their status are mostly still at the "jobseekers" level. It is believed that good reputation will be one of the factors of recommendation for them to be hired by the companies or organisations out there. However, CIFAS (2014) found that most of the fraudsters are those who are young and have just started working. However, BerryDunn (2015), they reported nearly $40 \%$ of perpetrators of the fraudsters are between the ages 36-45. The median losses increased with corresponding increases in the age of the fraudsters. The different findings lead this study to develop the second research hypothesis in this study.

\section{$\boldsymbol{H}_{2}:$ There is no significant difference between the age groups of employees on the Fraud Triangle model.}

There are also studies that the position that the employees hold also influence them to commit fraud. As quoted by Ewa and Udoayang (2012), several situations such as the absent or ineffective controls, lack of supervision or inadequate segregation of duties may create chances or opportunities to commit fraud (Kenyon \& Tilton, 2006). That is, the higher the position that an employee holds, the more likely the employee to commit fraud. In addition, most employees and managers who commits fraud tend to have a long tenure with organisation. In 
other words, since they are already had too many knowledge about the organisation, then it will be easier for them to manipulate the situation, Therefore, the third research hypothesis is developed.

$\boldsymbol{H}_{3}:$ There is no significant difference between the positions of groups of employees on the Fraud Triangle model.

Studies have suggested that a good understanding of religiosity would influence the employees' attitude and behaviour in performing their work tasks (Fariza \& Yusof, 2015). The belief that God exists and attitude that always brings God in their life will put the brakes on behaviours that are inconsistent with human's rules and God's rules. Therefore, a high understanding about religiosity will be correlated with attitude and behaviour and work outcomes. However, Muslims are also human beings with similar risk exposure towards fraud perpetration due to certain causes or motives (Rezaee \& Davani, 2013).

$\boldsymbol{H}_{4}:$ There is a no significant relationship between employees' religiosity and Fraud Triangle model.

\section{Research Design}

\section{Sample Selection}

This study focuses on employees in Islamic banks in Malaysia who are selected based on a simple random sampling (VanVoorhis \& Morgan, 2007). Based on the simple random sampling, because there are four variables, thus a minimum sample size of 90 should be collected to represent Islamic bank's population in Malaysia. To obtain 90 completed questionnaires, 180 questionnaires were distributed to the Islamic banks, by hand and through survey link (email) to the employees as well as the officers during office hours. With the help of head of Customer Service Division and a senior employee, the questionnaires were successfully distributed to the employees in the banks. For distribution by hand, the employees were given about a week to complete the questionnaires before the researchers went to their office for collection. Questionnaires using GoogleForm were distributed via email to the respondents, were submitted immediately after they have completed. Out of 180 questionnaires distributed, 109 questionnaires were completed and usable for data analysis in this study.

\section{Research Instrument}

This study utilises the questionnaire to achieve the research objectives of this study. The questions are developed based on reviewing the literature. The questionnaire in this study consists of three sections. The first section, Section A requests the respondents to provide their demographic information such as personal details and working background. The second section comprises of four parts which are related to the elements in Fraud Triangle. Part 1 is on perceived pressure, Part 2 is on perceived opportunity and Part 3 is on perceived rationalisation. All the questions in this section requests the respondents to choose one from five-point scale, in which scale "1" shows that they strongly disagree with the statement whereas scale " 5 " shows that they strongly agree with it.

In the second section, Second B, there are three parts. The first part requests the respondents to provide their views on the element of pressure towards asset misappropriation. They need to provide their perceptions or views on the level of pressure towards asset misappropriation perpetration by using a five-point scale. On the second part, the respondents were required to express their thoughts on the element of opportunity towards asset misappropriation. They need to provide their views on the level of opportunity from the given statements towards asset misappropriation perpetration by using the five-point scale. The third part requests the respondents on the element of rationalisation. The respondents are requested to provide their views on the level of rationalisation from the 
given statements towards asset misappropriation.

The third section, Section $\mathrm{C}$ requests the respondents related to religiosity. This study adopts Yasemin (2014), there are six indicators of a Muslim religiosity namely belief, ritual, devotion, experience, knowledge, devotion and consequences. These questions measure a Muslim's level of religiosity. The respondents are requested to complete this section using the five-point scale.

\section{Data Analyses}

There are many statistical analysis methods been utilised in this study in order to test the research hypotheses. This study utilises the T-Test, ANOVA and Pearson Correlation analyses. The data was analysed using the SPSS version 23.

\section{Results \& Discussion}

\section{Demographic Profile}

Diagram 1 shows the distribution of the respondents' gender of the 109 respondents. The distribution of the respondents' gender is almost equal with $50.5 \%$ and $49.5 \%$ respectively for male and female. Gender is one of the important factor to be taken into account as reported by the ACFE (2014). The report indicates that the male employees account for roughly two-thirds of the fraud cases. The ratio had been fairly consistent for the past 6 years which is between 2008 and 2014.

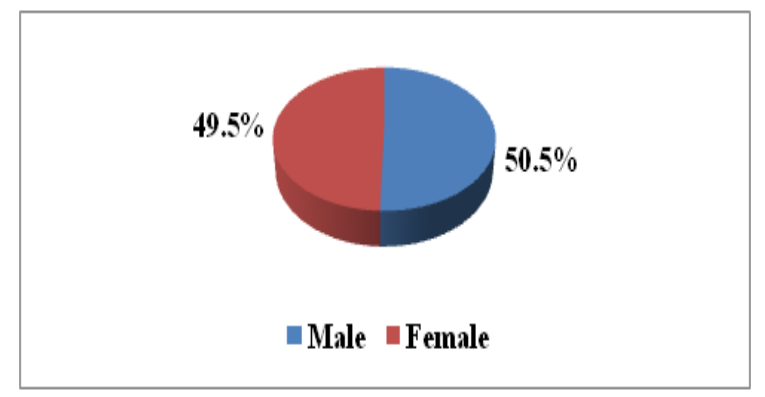

Figure 1: Gender
Diagram 2 shows the respondents' age distribution which is divided into 4 categories. Majority of the respondents' age range between 26 to 35 years old $(36.7 \%)$ and the minimum is at the age range between 46 to 55 years old $(4.6 \%)$.

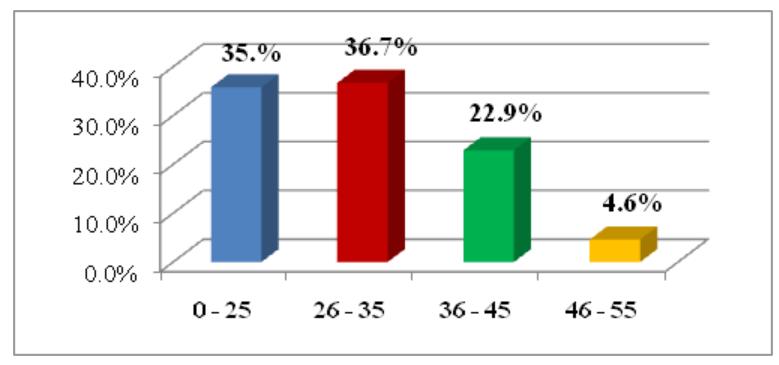

Figure 2: Age

As shown in Figure 3, approximately 33.03\% of the respondents are at the lower level management. About $34.86 \%$ of the respondents are holding the position in middle management which consists of the executives as well as senior executives, whilst the remaining of $32.11 \%$ are the employees those holding the position in top management level.

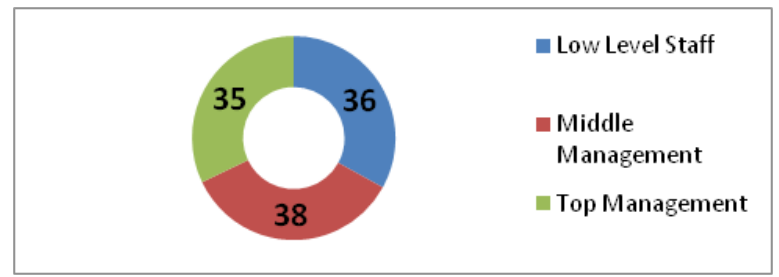

Figure 3: Position

Table 1 exhibits the descriptive statistics for the factor of religiosity. The table shows that the respondents have high level of agreed towards the ten statements of religiosity (pious level) since they scored above 4.00 for 9 out of 10 questions asked in this item while five questions have mean scores of more than 4.50 which are RG1, RG3, RG4, RG5 and RG7. Specifically, RG1 has a mean score of 4.64 (std. dev. = 0.631 ), RG3 has a mean score of 4.67 (std. dev. $=0.639), \mathrm{RG} 4$ has a mean score of 4.54 (std. dev. $=0.800)$, RG5 has a mean score of 4.59 (std. dev. $=0.612$ ) and RG7 has a mean 
Table 1: Perceived Religiosity

\begin{tabular}{|c|c|c|c|c|}
\hline Code & Statement & Mean & Median & Std. Deviation \\
\hline RG1 & $\begin{array}{l}\text { I believe in Allah SWT and committed to perform principle believe set } \\
\text { forth by Allah SWT. }\end{array}$ & 4.64 & 5.00 & 0.631 \\
\hline RG2 & $\begin{array}{l}\text { All my actions are influenced by the Prophet Muhammad's SAW's } \\
\text { Sunnah. }\end{array}$ & 4.41 & 5.00 & 0.723 \\
\hline RG3 & I believe that Allah SWT is always seeing my actions and deeds. & 4.67 & 5.00 & 0.639 \\
\hline RG4 & I feel discomfort when I missed my prayers. & 4.54 & 5.00 & 0.800 \\
\hline RG5 & $\begin{array}{l}\text { I always make sure that my action follows the direction stated in Qur'an } \\
\text { as all my bad and good deeds will be recorded by the Angels. }\end{array}$ & 4.59 & 5.00 & 0.612 \\
\hline RG6 & I read Al-Quran every day. & 3.99 & 4.00 & 0.897 \\
\hline RG7 & I believe all my actions will be judged in the thereafter. & 4.68 & 5.00 & 0.622 \\
\hline RG8 & I attend religious classes at least once a week. & 4.05 & 4.00 & 0.956 \\
\hline RG9 & Every month, I spend a small portion of my salary for sadaqah. & 4.40 & 4.00 & 0.654 \\
\hline RG10 & I always remember to say 'Shahada' before going to sleep. & 4.16 & 4.00 & 0.863 \\
\hline & All statement & 4.41 & 4.60 & 0.886 \\
\hline
\end{tabular}

$* \mathrm{RG}=$ Religiosity

score of 4.68 (std. dev. $=0.622$ ). The results indicates that the employees in the Islamic banks participated believe in Allah and their commitment to perform principle set forth by Allah and believe that Allah SWT is always seeing their actions and deeds and that factors cause them to feel discomfort when missed their prayers besides act as directed by Al-Quran and Sunnah since they are highly believe that their bad and good deeds will be totally recorded by the Angels (Malaikat) to be rewarded or punished during the judgment in the Hereafter.

\section{Perceived Pressure}

Table 2 explains the descriptive analysis on perceived pressure, the first element of Fraud Triangle. Five questions were given to Islamic banks' employees to measure their perceived pressure. The results show the pressure with the highest mean score is 4.04 gained by $\mathrm{P} 4$ (std. dev. $=1.039)$, followed by P3 with a mean score of 3.88 (std. dev. $=1.150)$ and P5 with a mean score of 3.86 (std. dev. $=0.946$ ). This study indicates that the pressure faced by the respondents are financial position due to increase in cost of living, the need to maintain organisation's reputation, personal urgent needs as well as using organisation's properties for personal business due to unavailable to go out for handling personal matters outside during office hours. However, the first two pressures are the more appealing ones since their mean scores are more than 4.00 and below but nearest to 4.00. In addition, among all the questions on pressure, P2 scores the lowest with a mean score of 3.68 (std. dev. $=1.167$ ) showing that among all these common types of life pressures, the least (but are still encountered) pressure dealt by the Islamic banks is the pressure that causes them to use bank's properties for personal purposes. 
GJAT | DECEMBER 2017 | VOL 7 ISSUE 2 | 86

ISSN : 2232-0474 | E-ISSN : 2232-0482

www.gjat.my

Table 2: Perceived Pressure

\begin{tabular}{|c|c|c|c|c|}
\hline Code & Statement & Mean & Median & Std. Deviation \\
\hline $\mathrm{P} 1$ & $\begin{array}{l}\text { In emergency, it is normal to use the bank's assets or cash for } \\
\text { personal matter. }\end{array}$ & 3.69 & 4.00 & 1.140 \\
\hline P2 & $\begin{array}{l}\text { I think it is nothing wrong to send private email by using the bank's } \\
\text { computer. }\end{array}$ & 3.68 & 4.00 & 1.167 \\
\hline P3 & $\begin{array}{l}\text { Bank will not be badly affected or harmed if small amount of money } \\
\text { is taken. }\end{array}$ & 3.88 & 4.00 & 1.150 \\
\hline P4 & $\begin{array}{l}\text { Due to financial pressure, bank's cash is available to be taken as a } \\
\text { borrowing. }\end{array}$ & 4.04 & 4.00 & 1.039 \\
\hline P5 & $\begin{array}{l}\text { In order to maintain bank's reputation, it is not an issue to make the } \\
\text { adjustment of certain immaterial amount or data. }\end{array}$ & 3.86 & 4.00 & 0.946 \\
\hline & All statement & 3.83 & 4.00 & 0.886 \\
\hline
\end{tabular}

\section{Perceived Opportunity}

Table 3 indicates the descriptive statistics of perceived opportunity, the second element in Fraud Triangle. Five questions are inquired in order to measure perceived opportunities which exist in the Islamic banks as well as within the duties as an employee of the bank itself. The mean scores are generated by averaging the mean scores for each question. In terms of perceived opportunity, the mean score for each question is near but lower than 4.00. As shown in the table, the highest mean score is earned by $\mathrm{O} 2$ with a mean score of 3.86 (std. dev. $=$ 0.616 ), followed by $\mathrm{O} 5$ with a mean score of 3.82 (std. dev. $=0.818$ ) and $\mathrm{O} 1$ and $\mathrm{O} 4$ with the same mean score of 3.75 (std. dev. $=0.795$ and 0.735 respectively). This study implies that the trust by banks in providing the time sheet to the employees to note their works and responsibilities done by themselves as well as no segregation of duties in supervising and monitoring the receipt and payment of cash are the two prominent opportunities which exist in the fulfilment of duties by Islamic banks' employees.

It can also be seen that $\mathrm{O} 3$ score the lowest with a mean score of 3.72 (std. dev. $=0.815$ ). Accordingly, this indicates close monitoring of the usage of bank's assets such as photocopy machine and desktop may lower the number of fraud perpetrated by the employees in the bank itself. In other words, perceived opportunities for the employees to commit fraud would be lower when there is a close supervision was made regarding the transaction and usage of bank's assets and properties.

\section{Perceived Rationalisation}

Table 4 depicts the descriptive analysis of perceived rationalisation, the third element of Fraud Triangle. The table shows the highest mean scores are $3.12($ std. dev. $=1.223$ ) possessed by $\mathrm{R} 5$, followed by R4 (mean score $=2.99$ ) (std. dev. $=1.005)$ and R3 (mean score $=2.80)$ (std. dev. $=1.007), \mathrm{R} 2$ (mean score $=2.73)$ (std. dev. $=1.033)$. The result indicates that the most common forms of justification made by the employees of those Islamic banks involved was borrowing money from bank's petty cash is a norm since everybody is doing the same. Then, the second highest justification usually made was it is not a wrong action to use office assets for personal purpose as long as it is for a good purpose such as to help the community. However, the mean scores range between 2.00 to 3.00 which means the respondents are neither agree nor disagree to the statements. 
Table 3: Perceived Opportunity

\begin{tabular}{|c|c|c|c|c|}
\hline Code & Statement & Mean & Median & Std. Deviation \\
\hline O1 & The record and documentation of assets have regularly been made. & 3.75 & 4.00 & 0.795 \\
\hline O2 & $\begin{array}{c}\text { The receipt and payment of cash are within a supervision by the same } \\
\text { employee on duty. }\end{array}$ & 3.86 & 4.00 & 0.616 \\
\hline O3 & $\begin{array}{c}\text { The use of bank's properties such as photocopy machine and desktop } \\
\text { are closely monitored by in-charged officer. }\end{array}$ & 3.72 & 4.00 & 0.815 \\
\hline O4 & $\begin{array}{c}\text { The process of recording in and out of cash are being done different } \\
\text { employees. }\end{array}$ & 3.75 & 4.00 & 0.735 \\
\hline O5 & $\begin{array}{c}\text { There employees are entrusted to note their works and responsibilities } \\
\text { done on a time sheet being provided. }\end{array}$ & 3.82 & 4.00 & 0.818 \\
\hline & All statement & 3.83 & 4.00 & 0.886 \\
\hline
\end{tabular}

*O=Opportunity

Table 4: Perceived Rationalisation

\begin{tabular}{|c|c|c|c|c|}
\hline Code & Statement & Mean & Median & Std. Deviation \\
\hline R1 & $\begin{array}{c}\text { I have underpaid even have contributed much for the bank, so I can } \\
\text { sometimes use the bank's assets for personal needs. }\end{array}$ & 2.60 & 3.00 & 1.028 \\
\hline R2 & $\begin{array}{c}\text { I am just borrowing the assets of the office, and I will return it back when I } \\
\text { am done. }\end{array}$ & 2.73 & 3.00 & 1.033 \\
\hline R3 & No one will suffer, if I use the office facilities for personal purpose. & 2.80 & 3.00 & 1.007 \\
\hline R4 & $\begin{array}{c}\text { I am using the office asset for a good purpose even if it is for my personal } \\
\text { purpose. }\end{array}$ & 2.99 & 3.00 & 1.005 \\
\hline R5 & $\begin{array}{c}\text { I believe that borrowing money from the bank's petty cash is a norm since } \\
\text { everybody is doing the same. }\end{array}$ & 3.12 & 3.00 & 1.223 \\
\hline & All statement & 3.83 & 3.00 & 0.886 \\
\hline
\end{tabular}

*R=Rationalisation

In contrast, the lowest and rarely used forms of justifications made are possessed by R1 with a mean score of 2.60 (std. dev. $=1.028)$, followed by $\mathrm{R} 2$ with a mean score of 2.73 (std. dev. = 1.033). The lowest score is for the justification made "I have underpaid even have contributed much for the bank, so I can sometimes use the bank's assets for personal needs" and "I am just borrowing the assets of the office, and I will return it back when I am done". The lowest mean scores of those justifications show that the employees are disagree with that statements and no issue of underpaid or silently borrowed bank's assets for other purposes.

\section{Gender and Perceived Fraud Triangle}

Table 5 presents the mean perception scores of male and female respondents for perceived pressure, perceived opportunity and perceived rationalisation are statistically different at 0.05 and 0.01 . For perceived pressure, the mean score for male (2.73) is higher than female (2.59). For perceived opportunity, the mean score for male (3.52) is also higher than female (3.35), and similar situation occur with perceived rationalisation in which the mean score for male (2.31) is higher than female (2.02). From the result, this study indicates that gender may create a different volume of fraud perpetrations. 
GJAT | DECEMBER 2017 | VOL 7 ISSUE 2 | 88

ISSN : 2232-0474 | E-ISSN : 2232-0482

www.gjat.my

Table 5: Gender and Perceived Fraud Triangle

\begin{tabular}{|c|c|c|c|c|}
\hline Dimension & Gender & Mean & $\mathrm{t}$-value & $\mathrm{p}$-value \\
\hline \multirow{2}{*}{ Perceived pressure } & Male & 2.73 & \multirow{2}{*}{-6.504} & \multirow{2}{*}{$0.000 * *$} \\
\hline & Female & 2.59 & & \\
\hline \multirow{2}{*}{ Perceived opportunity } & Male & 3.52 & \multirow{2}{*}{-2.234} & \multirow{2}{*}{$0.026^{*}$} \\
\hline & Female & 3.35 & & \\
\hline \multirow{2}{*}{ Perceived rationalisation } & Male & 2.31 & \multirow{2}{*}{-4.564} & \multirow{2}{*}{$0.000 * *$} \\
\hline & Female & 2.02 & & \\
\hline
\end{tabular}

*significant at 0.05

**significant at 0.01

It can be seen the male group of respondents is more prone towards fraud due to perceived pressure, perceived opportunity and perceived rationalisation.

Beltramini et al. (1984) reported that female college students were found to show more concern about the ethical issues as compared to their male counterparts. The finding was supported by Miesing and Preble (1985) in which females and those with religious conviction tended to be more ethical than males with little religious conviction. A study on significant relationship between gender and ethics was conducted by Ruegger and King (1992) and has also came out with similar result in which female were found to be more ethical than males in their perceptions of ethical business conducts. Ford and Richardson (1994) with his completed review shows that out of fourteen studies comparing gender in terms of their ethical behaviour, half of the results of his study supported that males being less ethical than females. Hence, $\mathrm{H}_{1}$ is rejected.

\section{Age and Perceived Fraud Triangle}

Table 6 provides the summary Statistics of One Way-ANOVA on the Difference between Age Range and Fraud Perpetration. The results show that the mean score for perceived rationalisation is not significant at $0.05(p<0.05)$, indicating that there is no difference in perceived rationalisation between the group of age. Indicating that in any age, their perceptions towards perceived rationalisation are almost same. While for perceived pressure and perceived opportunity, the mean scores are significant at $0.05(\mathrm{p}<0.05)$. These indicate that there are significant differences on their perceptions towards perceived pressure and perceived opportunity. Respondents in age group between 36 to 45 years are the most agree that perceived pressure leads a person to act fraudulently, while the age group 46 years and above are the least agree towards this perception.

This study indicates that the employees with the age ranging between 30 to 45 years old accounts for $50 \%$ to $54 \%$ of the perpetrators. The finding in this study is consistent with Dunnberry (2015) that found nearly $40 \%$ of perpetrators of the frauds studied were between the ages 36-45. This finding however is inconsistent with Mackevicius and Girunas (2013) that found older generation employees would commit less fraud because they have already achieved a certain level of career and hence, they try to sustain and secure their job. However, the type of fraud committed by the internal fraudsters normally depends on their ability to access information and what techniques they use in their fraudulent actions (CIFAS, 2013). Hence, $\mathrm{H}_{2}$ is rejected perceived opportunity and perceived pressure but not for perceived rationalisation. 
Table 6: Age and Perceived Fraud Triangle

\begin{tabular}{|c|c|c|c|c|}
\hline Dimension & Age & Mean & F-value & $\mathrm{p}$-value \\
\hline \multirow{3}{*}{ Perceived pressure } & 26 to 35 years & 2.38 & \multirow{3}{*}{2.872} & \multirow{3}{*}{$0.040 *$} \\
\hline & 36 to 45 years & 2.92 & & \\
\hline & $>46$ years & 2.32 & & \\
\hline \multirow{3}{*}{ Perceived opportunity } & 26 to 35 years & 3.47 & \multirow{3}{*}{2.811} & \multirow{3}{*}{$0.043^{*}$} \\
\hline & 36 to 45 years & 3.45 & & \\
\hline & $>46$ years & 2.88 & & \\
\hline Perceived rationalisation & $<25$ years & 2.44 & 1.681 & 0.176 \\
\hline
\end{tabular}

\section{Position and Perceived Fraud Triangle}

Table 7 shows the results of ANOVA on the difference between position and fraud perpetration. The mean score for perceived opportunity and rationalisation are not significant at $0.05(\mathrm{p}<0.05)$, indicating that there is no difference in perceived pressure and perceived opportunity between the two group of position. Indicating that in any position, their perceptions towards perceived pressure and perceived opportunity are almost same. However, the mean score for perceived rationalisation with top and middle management (2.36) and that of those low level employee (2.52) are significantly different at $5 \%$ level $(\mathrm{p}<0.05)$. This study indicates that perception on perceived rationalisation differs between positions. Specifically, those low level employees more agreed towards perceived rationalisation than the top and middle management.

Table 7: Position and Perceived Fraud Triangle

\begin{tabular}{|l|c|c|c|c|}
\hline \multicolumn{1}{|c|}{ Dimension } & Position & Mean & F-value & p-value \\
\hline \multirow{3}{*}{ Perceived pressure } & Top management & 2.39 & & \\
& Middle management & 2.97 & 4.238 & $0.017^{*}$ \\
& Low level employees & 2.61 & & \\
Perceived opportunity & Top management & 3.27 & & \multirow{2}{*}{0.149} \\
& Middle management & 3.62 & 1.936 & \\
Perceived rationalisation & Low level employees & 3.59 & & \\
& Top management & 2.18 & & \\
& Middle management & 2.53 & \multirow{2}{*}{1.963} & \\
& Low level employees & 2.22 & & \\
\hline
\end{tabular}

*significant at $0.05 \quad * *$ significant at 0.01 
The mean score for fraud triangle are also significantly different at $1 \%$ level $(\mathrm{p}<0.05)$. This study indicates that perception on fraud triangle differs between positions. Specifically, low level employees tend to agree more with the fraud triangle theory than those at the top and middle management. Hence, $\mathrm{H}_{3}$ is rejected for perceived pressure but not for perceived opportunity and perceived rationalisation.

As being indicated by ACFE (2012), the frequency of fraud occurrences between 2008 and 2012 shows that the number of fraud perpetrators which are comprising of executives and below recorded between $39 \%$ to $42 \%$, which is at high percentage that may cause fatal to the organisation. The number of managers that committed fraud were $37 \%$ to $41 \%$ whilst the remaining of $17 \%$ to $24 \%$ of the perpetrators were owners or directors of the organisations themselves. In addition, ACFE (2014) has also reported that perpetrators that have a greater access to the organisation's assets are at the better position and chance to over-ride any fraud controls.

\section{Religiosity and Perceived Fraud Triangle}

In this section, the correlation analyses were carried out to determine the relationships, if any, between religiosity and the elements in fraud triangle. Table 12 shows that religiosity is negatively but weakly correlated with perceived pressure $(\mathrm{r}=-0.389 ; \mathrm{p}<0.01)$, perceived rationalisation $(\mathrm{r}=-0.312 ; \mathrm{p}<0.01)$, fraud triangle $(\mathrm{r}=-0.425 ; \mathrm{p}<0.01)$, and positively, but weakly correlated with perceived opportunity $(\mathrm{r}=0.316 ; \mathrm{p}<0.01)$. That is say, to a small extent, the more the respondents comply with the shariah the more they are associated with a decrease in pressure, rationalisation, fraud and vice versa. And, to a small extent, the more they are in compliance with the shariah, the more they are associated with an increase in opportunity and vice versa.

Table 8 shows that religiosity is negatively and weakly correlated with perceived pressure $(\mathrm{r}=-0.389 ; \mathrm{p}<0.01)$. That is, to a small extent, an increase of religiosity is associated with a decrease in perceived pressure, and vice versa. The result shows that religiosity is positively but weakly correlated with perceived opportunity $(\mathrm{r}=0.316 ; \mathrm{p}<0.01)$. That is, to a small extent, an increase of religiosity is associated with an increase in perceived opportunity, and vice versa. Religiosity is negatively and weakly correlated with perceived rationalisation $(\mathrm{r}=$ $0.312 ; \mathrm{p}<0.01)$. That is, to a small extent, an increase of religiosity is associated with a decrease in perceived opportunity, and vice versa. Religiosity is negatively and weakly correlated with fraud triangle $(\mathrm{r}=-0.425$; $\mathrm{p}<0.01)$. That is, to a small extent, an increase of religiosity is associated with a decrease in fraud triangle, and vice versa. Hence, $\mathrm{H} 4$ is rejected.

\begin{tabular}{|l|l|l|}
\hline \multirow{2}{*}{} & \multicolumn{2}{|l|}{ Religiosity } \\
\cline { 2 - 3 } Perceived pressure & Coefficient of Correlation $(\mathrm{r})$ & $\mathrm{p}$-value \\
\hline Perceived opportunity & -0.389 & $0.000 * *$ \\
\hline Perceived rationalisation & 0.316 & $0.000 * *$ \\
\hline
\end{tabular}

\footnotetext{
** Significant at 0.01
} 


\section{Conclusion}

This study examines whether Islamic bank employees' profiles influence them to commit fraud. Therefore, this study aims to examine whether gender, age, position and religiosity would influence them to commit asset misappropriation. By utilising the Fraud Triangle theory, this study conducted questionnaire survey to 109 employees in the Islamic banks in Malaysia. The results show significant relationship on gender, age, position and religiosity in influencing the Islamic bank employees to commit asset misappropriation.

This study is not without limitations. First, the sample in this study consists of Muslim employees who are currently working in the Islamic banks. The sample is 109 and thus, the results of this study may be different if a larger sample size is used. Secondly, this study uses the Fraud Triangle model to examine the employees' profile on perceived fraud. There are other models such as the Fraud Diamond model which may different results and perspective.

The findings of this study enhance the existing literature and contribute further in the body of knowledge in the area of asset misappropriation. Findings are valuable for related parties including policy makers, banks' managers as well as practitioners in improving safety mechanisms in Malaysia. There is also triggering future studies on fraud related issues especially in asset misappropriation in Malaysia which is not widely available.

\section{Reference}

ACFE (2014). Report to the nations on occupational fraud and abuse 2014 global fraud study.

Adeniji, A. (2004): Auditing and Investigation. Lagos, Value Analysis Publishers
Alam, K.F. (1995). Attitudes towards business ethics of business students in Malaysia.

Journal of Business Ethics, 14: 309-313.

Albrecht, W. S., Albrecht, C. C., \& Albrecht, C. O. (2006). Fraud examination (2nd ed.). Mason, $\mathrm{OH}$ : Thomson Higher Education

Arnould, E., Price, L. \& Zikhan, G. (2004). Consumers (2nd ed.). New York: McGraw-Hill.

Beltramini, R.F., Peterson, R.A. \& Kozmetsky, G. (1984) Concerns of college students regarding

Business Ethics: A Replication. Journal of Business Ethics, 10: 733-738.

Bernama, (2013, December 6), Hundreds Of Millions Swindled From Banks In Past 5 Years, Mostly By Employee, Say Police, Retrieved from www.themalaysianinsider.com

BerryDunn (2015). Fraud update for financial institutions: How to mitigate the damage? http:// www.berrydunn.com/news-detail/fraud-updatefor-financial-institutions

Bierstaker, J.L, Brody, R.G \& Pacini, C, (2006). Accountants' perceptions regarding fraud detection and prevention methods, Managerial Auditing Journal, 21(5): 520-5354

Campos, J.E. \& Pradhan, S. (2007). The many faces of corruption: Tracking vulnerabilities at the sector level, The World Bank, Washington DC.

Chapple, L., Ferguson, C \& Kang, D. (2007). Corporate governance and misappropriation http://www.accg.mq.edu.au/Accg_docs/pdf/ seminar_papers/2007/Colin_Ferguson.pdf

CIFAS (2013). Employee fraud scape: Depicting the UK fraud landscape, https://www.cifas.org. uk/secure/contentPORT/uploads/documents/ External-Employee_Fraudscape_CIFAS webversion.pdf 
Ewa, U. E., \& Udoayang, J. O. (2012). The impact of internal control design on banks' ability to investigate employee fraud, and life style and fraud detection in Nigeria. International Journal of Research in Economics \& Social Sciences. 2(2): 32-43.

Fariza, M.S \& Yusof (2015). Religiosity of Muslim adolescents from single parent families living in Government-subsidised settlement, Global Journal Al Thaqafah, 5(2) http://www. gjat.my/gjat122015-AR/8820150502-ar.pdf

Giacalone, R.A. \& Jurkiewicz, C.L. (2003). Toward a science of workplace spirituality. Handbook of workplace spirituality and organizational performance, 3-28.

Holtfreter K., Reisig M. D., Mears D. P., Wolfe S. E. (2014). Financial exploitation of the elderly in a consumer context: Final report. Washington, DC: National Institute of Justice.

Jamal, J.E (2003). On Wings of Diesel: Spiritual Space and Religious Imagination in Pakistani Truck Decoration, RES: Anthropology and Aesthetics 43 (Spring 2003): 187-202.

Kenyon, W \& Tilton, P.D. (2006). Potential Red Flags and Fraud Detection Techniques, A Guide to Forensic Accounting Investigation, John Willey \& Sons, Inc, 119-160.

KPMG Fraud Survey (2013) KPMG Malaysia Fraud, Bribery and Corruption Survey 2013, http://www.frank-cs.org/cms/pdfs/KPMG/ KPMG_Malaysia_Survey_13.1.14.pdf

Levi, M. (2010). Public and Private Policing of Financial Crimes: The Struggle for Coordination, Journal of Criminal Justice and Security, 12(4): 343-354

Mackevicius, J., Girunas, L. (2013). Transformational research of the fraud triangle. Economics, 92 (4): 150-163.
Miesing, P \& Preble, J.F (1985). A comparison of five business philosophies. Journal of Business Ethics 4. (6): 465-476

Murphy, P.R. \& Dacin, M.T(2011). Psychological Pathways to Fraud: Understanding and Preventing Fraud in Organisations, Journal of Business Ethics 101: 601-618

Peterson, B.K \& Buckhoff, T.A (2004). Interstate Business College: A Case Study in Fraud Examination. Issues in Accounting Education, 19(4): 505-527.

Rezaee, Z., Crumbley, L. \& Elmore, R. (2004) Forensic Accounting Education: A Survey of

Academics and Practitioners. Advances in Accounting Education Teaching and Curriculum Innovations, 6, 193-232.

Rezaee, Z \& Davani, G. (2013), Does financial reporting fraud recognise borders? Evidence from bank fraud in Iran, Journal of Forensic and Investigative Accounting, 5(2): 224-238

Rest, J. (1986). Moral Development: Advances in Research and Theory, Praeger, New York.

RICK. (2011). Iran Makes New Arrests in Fraud Case.

Ruegger D., King E.W. (1992). A Study of the Effect of Age and Gender upon Student Business Ethics. Journal of Business Ethics 11:179-186

Siregar, S.V \& Tenoyo, B (2015). Fraud awareness survey of private sector in Indonesia, Journal of Financial Crime, 22(3): 329-346.

Stewart, L. (2007). Managing Government Employees: how to motivate your people, deal with difficult issues and achieve tangible results, Amacom, New York, 11-19 
VanVoorhis, C.R.W \& Morgan, B.L (2007). Understanding power and rules of thumb for determining sample sizes, Tutorials in Quantitative Methods for Psychology, 3(2): $43-50$

Yasemin, E. (2014). The five dimensions of Muslim religiosity: Results of an empirical study, Methods, Data and Analyses. 8(1): 53-78 
